\title{
Environmental Sustainability at the Olympic Games: Comparing Rio 2016 and Tokyo 2020 Games $^{1}$
}

\author{
Kathryn Rowberg ${ }^{1}$ and Meg Rincker ${ }^{1}$
}

\begin{abstract}
The modern Olympic Games have evolved from events fostering international peace and goodwill to showcases of athleticism and commercialism. More recently sustainability became a pillar of the Game site selection process. This paper focuses on two Olympic Games: Rio 2016 (completed) and Tokyo 2020 (upcoming). The goals of Sustainability Plans and pre-game reports for the two Olympic sites are analyzed using weighted summation method of Multi-attribute Value theory and the framework of environmental, economic and social-cultural sustainability, with emphasis on environmental sustainability. Post-game analysis and legacy stories are reviewed for Rio 2016. Application of legacy stories to future Olympics sites is examined. Last, Rio 2016 and Tokyo 2020, in terms of actual and anticipated success in sustainability initiatives, are compared for the impact these two Games may have on future Olympic Game sites.
\end{abstract}

Keywords: Sustainability, environmental sustainability, Olympic Games, Rio 2016, Tokyo 2020

\section{Introduction}

Although the ancient Olympic Games (OG) were religious festivals and displays of political might, when Pierre de Coubertin founded the Modern Olympic games in Rome in 1896, he envisioned athletic competition transcending military competition between states and leading to international cooperation. Hosting the Olympic and Paralympic games can raise a country's international visibility and prestige--particularly so if the country has not hosted before.

Efforts to reform the bidding and hosting process appear to solve some problems while creating others. For example, in preparation for the 1976 Summer Games, Montreal proudly unveiled its Big “O” Stadium costing \$1.5b USD. Today, colloquially known as the Big "Owe," it costs $\$ 32 \mathrm{~m}$ USD a year just to maintain it. Only tearing it down would cost more than the maintenance (Todd, 2016, July 7). In response to such overspending, the 1984 Los Angeles Games restructured the Olympic financial model, requiring that multi-million dollar Official Olympic sponsors, or multinational corporations, pay a larger share of the short-term costs of hosting the Games. This model, combined with a sharp jump in television broadcast revenue made L.A. the only city to turn a profit hosting the Olympics, finishing with a $\$ 215 \mathrm{~m}$ US operating surplus (McBride, 2018). Unfortunately, this strategy shuts out local businesses who could benefit from sales (Boykoff, 2016) and leads to a sort of iron-triangle cooperation between the city, country and International Olympic Committee (IOC), and corporate sponsors who maintain complete brand control in the Olympic Economic zone (Sinclair, 2012).

${ }^{1}$ We thank James Gross for Excellent Research Assistance. This work was supported, in part, by a Purdue University Northwest Exploratory Grant. 
Anti-Olympic groups ask, How sensible is the overall project of the OG? Why should they be held in different cities, saddling generations with pollution, garbage, excess capacity and debt just to pay for buildings used for only two months (Bray 2011)? Should developing countries be pressured to host when they have other priorities (Bray, 2011)? For too long, those who have to deal with the tax burden, inconvenience and garbage associated with hosting an $\mathrm{OG}$, are those who fail to reap actual benefits from hosting. The opening ceremonies of the XXXII Olympiad will be held in Tokyo, Japan from 24 July to 9 August 2020. These games will include a record 207 Nations, 12,000 athletes, and 324 events in 33 sports (IOC, n.d.) with the paralympics to follow. The average country cost to host a Summer OG is $\$ 5.2 \mathrm{~b}$ US. This includes building stadiums and arenas for athletic events, constructing hotels for tourists, updating transportation for spectators, dealing with garbage, pollution, and traffic created by anticipated 920,000 visitors to Japan each of the 20 days of the games (Osada et al., 2016). Ticket sales, advertising, and athlete fees of $\$ 0.6 \mathrm{~m}$ US do not cover these costs. As a backdrop, Tokyo 2020 OG is situated in a country associated with leading the global community on dealing with climate change. The 1997 Kyoto Protocol set in motion the most comprehensive and proportional plan to get countries to commit to reducing their greenhouse gas emissions (United Nations Framework Convention on Climate Change, 1998).

Compare this projected record attendance with the reality of the Rio 2016 Games, which have been criticized for the poor water conditions for athletes, over-focus on planting trees and emphasis on having athletes eat low on the food chain in the Olympic Village for a green sustainability strategy. Yet, Rio itself was host to the Earth Summit in 1992 to discuss climate change. The non-binding documents signed at the Earth Summit included what would come to be called Agenda 21 (Guthoff, 2017). The UN defines Agenda 21 as "a comprehensive plan of action to be taken globally, nationally and locally by organizations of the United Nations System, Governments, and Major Groups in every area in which human impacts on the environment "(World Commission on Environment and Development, 1992). Over the long term, Rio may benefit enormously from being the first Latin American OG host outside of Mexico City in 1968. This paper describes the evolution of an agenda to make the OG environmentally sustainable, and to create a screening assessment of the relative success of activities in connection with the Rio 2106 OG and the upcoming Tokyo 2020 OG.

\section{International Conferences and Mainstreaming of Sustainability into the OG}

Sustainability is defined as "development that meets the needs of the present without compromising the ability of future generations to meet their own needs" (World Commission on Environment and Development, 1987, p. 16). Domestic environmental groups, as well as international organizations like the United Nations (UN), have forced sustainable development onto the international agenda, including at events like the Olympic Games. Specifically, the UN states that "sustainable development seeks to achieve, in a balanced manner, economic development, social development and environmental protection" (World Commission on Environment and Development, 2015). The UN has shown its commitment to sustainability, despite having other top 
global priorities. Sustainability was present within the eight Millennium Development Goals formed by the United Nations in the Millennium Summit in 2000 for evaluation by 2017. Specifically, Goal \#7 was ensure environmental sustainability. Moving forward to 2015, the UN articulated 17 Sustainable Development Goals (SDGs), which are development principles with targets that all 194 member states should seek to meet by 2030. In particular, Rio considered UN SDGs 7, 9, 12, 13, 15, and 17 to create focus areas of infrastructure and natural sites, sourcing and resource management, and address mobility and climate change, but as mentioned previously Brazil did not perform well on Goal 6 Clean water and Sanitation.

In IOC documents, the current meaning of sustainability has evolved to include the amalgamation of environment, economic and social issues, but the origin of this emphasis is traced back to IOC's presence at the 1992 UN Earth Summit in Rio de Janeiro where Agenda 21 was formed, a plan for worldwide sustainable development. Activists and leaders or advocacy coalitions in the global environmental community are key forces (Keck \& Sikkink, 1998), pushing for other international organizations like the IOC to adopt sustainability. By 1996 the IOC revised the Olympic Charter to enumerate the importance of sustainable development in the Olympic Movement (OM; IOC, 1996, p.11). From this inauspicious beginning, the concept of sustainable development in the OG evolved to include terms such as sustainability, green legacy, low carbon, zero waste, biodiversity protection, water conservation, net zero energy and zero impact (Ross \& Leopkey, 2017).

Tracing the evolution of the concept of sustainability requires chronology gymnastics due to multi-year lag time from IOC pronouncement to bidding on and hosting an OG. Ross and Leopkey trace the evolution of environmental practices of the OM into three phases: environment, sustainability and zero impact. Several examples are especially pertinent. Beginning in 1997 with the newly added sustainable development clause in the Olympic Charter, Olympic bids contained sections dedicated to sustainable development and environmental protection leading to Athens 2004. In 1999, after the IOC adopted Agenda 21 sustainability development principles and added bid recommendations of environmental restoration, Torino added a green legacy to its bid for the 2006 Olympics (Ross \& Loepkey, 2017).

Although it appears the IOC is setting the pace, in reality the bidding cities 'upped the ante' on sustainable development in each subsequent bid of host an OG. In 1997 Torino added a social component to sustainability, while Helsinki's bid suggested developing assessment. However, it wasn't until 2000 that the IOC instituted the Olympic Games Impact Program to assess sustainable development at the OG. After that announcement, Sochi 2014 used the environmental standards of the World Health Organization for assessment. In 2003, Vancouver's 2010 bid expanded Torino's 1997 bid containing the social aspect of sustainability to include financial, economic, social and environment aspects of sustainability (Ross \& Loepkey, 2017). These bids reflect the effort of $\mathrm{OG}$ candidates to articulate meaningful attributes of sustainable development with each successive bidding city furthering the meaning of sustainability. Presently the internationally recognized pillars of sustainable development are environment, sociocultural and economic. The IOC declined to mandate specific sustainability goals for an OG bid, and instead stated that it will work with the candidate city to develop a 
sustainability strategy aligned with the five IOC sustainability focus areas, establish a sustainability management system, and deliver sustainability reports (IOC, 2017a).

In 2005, London announced its bid to host in 2012 and used the phrases low carbon, zero waste, and protection of biodiversity. In 2009, Rio de Janeiro's bid for 2016 OG included the concepts of water conservation, renewable energy, carbon neutrality. In 2013, Tokyo's 2020 bid listed zero waste and restoration of urban nature (Ross \& Loepkey, 2017). All these bids occurred by 2013, yet it was not until 2014 that the IOC published Agenda 2020 which included two broad recommendations for sustainability at the OG: include sustainability in all aspects of the OG and include within the OM's daily operation (IOC, 2015). Since then, the IOC recognized that "sustainability is a continually evolving and changing process" (IOC, 2017, p. 49) and committed to reviewing its sustainability strategy every four years. With the implementation of Global Reporting Initiative (which set standards for reporting principles for defining report content and quality) examination of plans, efforts, applications and fulfillment of strategic goals for sustainable development is more feasible than ever (IOC, 2011). The IOC uses the post-games reports to commit to Agenda 2020, namely to ensure postGames monitoring of the Games legacy. Although this will be expected for the 2024 OG, it is likely that prior OG will voluntarily make efforts in this area. Rio 2016 has yet to submit a post-games report.

The Rio 2016 Games were heralded as most sustainable in their planning, and carbon neutrality through reforestation, but were still criticized for overemphasis on tree planting, the fact that some projects were not completed on time meaning construction for naught, and a dam failure that led to arsenic leeching in a river. But undoubtedly, the most egregious issue at the Rio 2016 Games was the poor water quality encountered by swimmers and athletes using aquatic vessels such as sailboats, canoes, sculls in Guanabara Bay (Guthoff, 2017). Post-games analyses by the sport federations generated a water quality management plan with common guidelines (standards and testing protocols) for future host cities. They predict that following such a plan will secure good water quality for the athletes and for the city afterwards (IOC, 2017b).

\section{Environmental Sustainability incorporated into Rio 2016 and Tokyo 2020 Plans}

In 2014, the International Olympic Committee (IOC) published Olympic Agenda 2020 (IOC, 2015), listing 40 recommendations to address concerns of credibility, youth games and sustainability. Two recommendations emphasized sustainability-in OG and OM. These two reflected the United Nations Millenium Development Goal \#7 Ensure environmental stability (UN, 2000). Furthering this effort, the UN adopted Agenda 2030 creating 17 sustainable development goals (SGDs; World Commission on Environment and Development, 2015) and recognized the powerful role of sport in this quest. Then in 2016, the IOC addressed how it would contribute to the 2030 Agenda and SDGs at the Olympic Games in the IOC Sustainability Strategy. Pointedly, the IOC expected to "include sustainability in all aspects of the Olympic Games and within the Olympic Movement's daily operations” (IOC, 2017a).

Although Rio 2016 was selected as a host city in 2009, much earlier than the IOC move towards environmental sustainability, the candidature application for Rio 2016 included 
several aspects of sustainability. In Live Your Passion: Rio 2016 Candidate City (Rio, 2009), the areas of focus for the environmental and sustainability plans were listed as water conservation, renewable energy, carbon neutral Games, and waste management and social responsibility. After further deliberation, the sustainability management plan listed nine dimensions of environmental sustainability: 1. Water treatment and conservation 2. Environmental awareness 3. Use and management of renewable energy 4. Games neutral in carbon, air quality and transport 5. Protection of soils and ecosystems 6. Sustainable design and construction 7. Reforestation, biodiversity and culture 8. Shopping and ecological certification 9. Solid waste management (Rio 2016 Bid Committee, 2008, volume 1, page 92.). The IOC comments on the candidature file indicated that Brazil had small cars using ethanol, taxis using methane, signed the Kyoto Protocol, had acceptable air quality (with a few exceptions for particulate matter) and the drinking water quality was acceptable (IOC, 2009).

Similarly, this paradigm shift of sustainable development occurred after Tokyo offered the bid in 2009 and candidature file in 2011 for the 2020 Olympics Games. However, Tokyo's bid included its sustainability concept of "Be better, together-For the people and the planet." Tokyo was elected to be the host city for the 2020 Olympic games in 2013, a year before IOC adopted the Olympic Agenda 2020. Nevertheless, in the High-level Sustainability Plan (Tokyo Organising Committee for the Olympic and Paralympic Games, 2016), Tokyo 2020 had fully embraced sustainable development in five main sustainability issues: climate change; resource management; natural environment and biodiversity; human rights, labor rights and fair business practices; and involvement, cooperation and communication. By July of 2016, the Tokyo 2020 Action and Legacy Plan promised gains in sports and health; urban planning and sustainability; culture and education; economy the technology; and recovery, nationwide benefits and global communications. One example is the goal of using recycled metals from donated electronics in the creation of the Olympic medals. Not only were the metals recycled instead of landfilled, but the project generated enthusiasm and buy-in from around the nation.

To address the unsustainable high cost of OG, the IOC published the New Norm (IOC, 2018a) which provided 118 measures to increase cost-effectiveness and transfer of services from game to game. In October 2018, the Executive Board meeting reported that by applying around 90 of the New Norm measures, Tokyo 2020, would be saving $\$ 4.3 \mathrm{~b}$ USD through the review of the Venue Master Plan and from the operational budget (IOC, 2018b, October 4). Unfortunately, this was too late for Rio 2016.

This paper therefore compares the sustainability efforts of the Olympics Games in Rio 2016 and Tokyo 2020 with respect to the environmental hub of sustainability. We report for both Rio 2016 Games and the Tokyo 2020 Games sustainability initiatives in the following nine dimensions: water treatment and conservation; environmental awareness; use and management of renewable energy; games neutral in carbon, air quality and transport; protection of soils and ecosystems; sustainable design and construction; reforestation, biodiversity and culture; shopping and ecological certification; and solid waste management. 


\title{
4. Method
}

Sustainability assessment must address several factors, most notably for this assessment: level of analysis desired (screening or evaluative), objectives to assess, attributes to examine, and weighting of the attributes (van Hervejnin, n.d.). The purpose of this assessment is to provide early feedback on environmental activities/events and provide input for refining the bidding process for the OG hosts. To assess environmental sustainability, an evaluation table or matrix was created using the Rio's environmental sustainability dimensions (Rio Bid Committee, 2008, volume 1, page 92) as the objectives (heading in the appendix).

Below each heading, activities (or events) were listed which impacted the heading and were scripted to represent positive weight $\left(\mathrm{w}_{\mathrm{i}}=+1\right)$ or negative weight $\left(\mathrm{w}_{\mathrm{i}}=-1\right)$ with regards to performance or completion of the sustainability dimension. Normal font was positive weight and italics was negative.

In this study, a simplified weighted summation methodology was used. Because this is a screening analysis, the weighs were a direct estimation of the magnitude of the effects of the activity and listed as either ' 0 ' for prior to event, ' 1 ' for moderate effect or ' 2 ' for strong effect with the value given in parentheses after the activity. A simple ternary weight system was chosen due to the timing of the assessment. Rio 2016 has yet to complete a final post-game report to use in this analysis; therefore, items for Rio in the matrix come from their bid, pre-game report and from media reporting. Similarly, Tokyo 2020 has yet to host the OG and complete a final post-game report (anticipated in 2023) to use in this analysis. Likewise, items in the matrix for Tokyo come from their bid, pre-game report and from media reporting.

The weighted sums for each issue were calculated using the formula:

\author{
weighted sum $=\sum_{i=1}^{N} w_{i} v_{i}$ \\ equation 1.
}

With $\mathrm{N}$ being the number of activities, $w_{i}$ as the weight of the activity $i$ and $v_{i}$ as the value of activity $i$.

The weighted sums were listed immediately below each objective in the appendices. The total of the weighted sums is the score for environmental sustainability and was listed below the name of the Olympic Games host city in each appendix.

\section{Results}

Appendix 1 is an evaluation matrix for Rio 2016 which lists both positive and negative attributes for each of the nine environmental sustainability dimensions. The weighted sum for each dimension was determined and the sum of these is the score of 8 for Rio 2016 using this environmental sustainability assessment. Appendix 2 follows the same evaluation matrix format for Tokyo 2020 which scored 16 in this environmental sustainability assessment. These scores are temporal and will change as more information is released and as events occur. For Rio 2016, the score of 8 may change when more information is released, especially a post-games report. Tokyo 2020 Games have not happened yet, but many environmental activities are already implemented and have value assigned to them. After the games occur, the value of the other activities can be estimated. 


\section{Discussion}

The nine sustainability dimensions for Rio 2016 (Rio 2016 Organising Committee for the Olympic and Paralympic Games, 2013, p.10) were used as the objectives for two main reasons. First, acting rationally, the Rio 2016 Games should choose dimensions for sustainability in which it could reasonably expect to advance some sort of policy goal. We recognize that different countries might pursue different policies within these dimensions, based on their unique characteristics and comparative advantage, but in this screening assessment was recorded as the presence or absence of policy initiatives in each of the nine dimensions.

Second, even though Brazil is an emerging economy and Japan is a highly developed economy, it struck us as more reasonable to impose Rio's framework on Tokyo than retroactively imposing a framework Tokyo chose on Rio. Finally, when developing frameworks like sustainability strategies for international law, research and policy evaluation must include both developed and developing countries in order to be effective. This case selection strategy is employed in other research. For example, if International Organizations claim that decentralization is a good institutional reform for promoting women, then research testing that proposition must be carried out in a variety of countries (see Rincker, 2017), not just advanced industrialized democracies but a range of countries. For Rio 2016, the score of 8 represents a rough estimate of the assessment of the environmental sustainability at the Olympics. For Tokyo 2020, the score of 16 is larger; however, none of the values are normalized so direct comparison is not as important as reviewing the strengths and weakness of the attributes for the dimensions. For example, Tokyo may thrive under additional scrutiny and address some areas that are unaddressed or negatives. In fact, Tokyo did address the unfair practices associated with forest products it imported (Tokyo Organising Committee of the Olympic and Paralympic Games, 2019). We would expect Tokyo 2020's sustainability strategy to be more comprehensive than Rio's based on disparate wealth levels, Tokyo learning from the Rio Games and the recommendations in the New Norm (IOC, 2018a). The New Norm was published after Rio 2016 yet the recommendations it provided might have benefitted Rio. Tokyo 2020 estimates it will shave \$4.3b US from its expenditures through implementing several of the recommendations (IOC, 2018b).

Bidding itself is subject not only to coercive pressures from the IOC but also mimetic and normative pressure from other candidate and host cities (Ross \& Loepkey, 2017). In the excitement of being the first South American country to host the Olympics, environmental goals in the Rio bid may have been an unrealistic reach. The impression of Rio's polluted waterways may cast a pale on the positive legacy of cleaner water. Although not reaching the bid goal of $80 \%$, by the time of the Olympics, the percentage of treated sewage rose from 12 to 60\% (Clarke, 2016, March 9). Perhaps the lesson here is to give credit to a bidding city which is more realistic concerning changes and dedicated to a legacy of continuing improvement.

The term 'resilience' is not coined, yet is demonstrated by the appearance of the Tokyo 2020 Olympic flame in regions recovering from the Great East Japan earthquake of 2011. Resilience is an aspect of sustainability and recognition should be given to people 
who "overcome difficulty and show persistence" (Tokyo Organising Committee for the Olympic and Paralympic Games, 2019). Rio, in retrospect, mustered resilience dealing with both the Zika virus and an economic downturn around the time of the Olympics. These extenuating circumstances are not included in this sustainability assessment, but likely should be.

Last, the nine dimensions are not totally independent from one another. Reflecting the environment itself, there is spillover in one negative dimension to other dimensions, such as Tokyo 2020 not sustainably sourcing its timber. The weighted sums should be analyzed for redundancy to determine if an attribute has more impact than expected.

\section{Conclusion}

A weighted sum assessment of the dimensions of the Rio 2016 and Tokyo 2020 Olympic Games suggest scores of 8 and 14, respectively. These scores are temporal and will change as event happen and information is released. Both games have completed several outstanding activities related to environmental sustainability and also have experienced problems with environmental quality or unfair practices. It is noteworthy that over previous games, Rio 2016 and Tokyo 2020, located in countries that have played leading roles in setting the international environmental agenda, still have much to do to give the Olympic Games a legacy of sustainability.

\section{References}

Boykoff, Jules. (2016). Power games: A political history of the Olympics. Verso: New York.

Bray, Ellen. (2011). The curse of good hospitality: Why developing countries shouldn't host international sporting events. SAIS Review of International Affairs, 31(1), 99-102.

Cashman, Richard (2002). Impact of the games on Olympic host cities. Retrieved from http://www.dormivigilia.com/wp-content/uploads/2010/01/cashman.pdf

Clarke, Liz. (2016, Mar 9), USOC, athletes navigate questions swirling around Rio's contaminated waters. Washington Post. Retrieved from https://www.washingtonpost.com/sports/olympics/us-athletesfocused-on-medals-not-water-quality-ahead-of-rio-olympics/2016/03/09/def96766-e63b-11e5b0fd-073d5930a7b7_story.html?utm_term=.780deadbc126

Goldblatt, David. (2016). The games: A global history of the Olympics. W.W. Norton \& Company: New York.

Guthoff, Ian. (2017). Creating a sustainable Olympic games. Syracuse Journal of International Law and Commerce, 44(2), 355-375.

IOC. (n.d.). Tokyo 2020. Retrieved from https://www.olympic.org/tokyo-2020

IOC. (1996). Olympic charter. Lausanne: Author. Retrieved from https://www.olympic.org/olympic-studiescentre/collections/official-publications/olympic-charters

IOC. (2009). Report of the 2016 IOC evaluation commission: Games of the XXXI Olympiad. Lausanne: Author.

IOC. (2011). Technical manual on Olympic games impact (5th Ed.). Lausanne: Author.

IOC. (2015). Olympic agenda 2020: Implementation plan. Lausanne: Author. Retrieved from https://stillmed.olympic.org/media/Document\%20Library/OlympicOrg/Documents/OlympicAgenda-2020/Olympic-Agenda-2020-Implementation-Plan-2015-and-Beyond.pdf

IOC. (2017a). Sustainability strategy. Lausanne: Author. Retrieved from https://www.olympic.org/ /media/Document\%20Library/OlympicOrg/Factsheets-ReferenceDocuments/Sustainability/IOC-Sustainability-Strategy-Long-version-v12.pdf?la=en

IOC. (2017b). IF-Sustainability Case Study. Water Quality Working Group. Retrieved from https://stillmed.olympic.org/media/Document\%20Library/OlympicOrg/IOC/What-We-

Do/celebrate-olympic-games/Sustainability/Case-Studies/2017/IF\%20SCS-

WATER\%20QUALITY.pdf\#_ga=2.126667780.84412320.1538766550-601309461.1538168927 
IOC (2018a). Olympic agenda 2020: Olympic games: the new norm. Lausanne: Author.

IOC. (2018b). Olympic agenda 2020 and its new norm save Tokyo 2020 USD 4.3 billion. Olympic news. Retrieved from https://www.olympic.org/news/olympic-agenda-2020-and-its-new-norm-savestokyo-2020-usd-4-3-billion

Keck, Margaret E. and Sikkink, Kathryn. (1998). Activists beyond borders: Advocacy networks in international politics. Cornell University Press.

McBride, James. (2018). The economies of hosting the Olympics. Retrieved from: https://www.cfr.org/backgrounder/economics-hosting-olympic-games

Osada, Mitsuhiro, Ojima, Mayumi, Kurachi, Yoshiyuki, Miura, Ko \& Kawamoto, Takuji. (2016). Economic Impact of the Tokyo 2020 Olympic Games. Retrieved from https://www.boj.or.jp/en/research/brp/ron_2016/data/ron160121b.pdf

Rincker, Meg. (2017). Empowered by design: Decentralization and the gender policy trifecta. Temple University Press.

Rio 2016 Bid Committee. (2008). Rio 2016 candidature file. Rio de Janiero: Author.

Rio 2016 Organising Committee for the Olympic and Paralympic Games. (2013). Sustainability management plan: Rio 2016 Olympic and Paralympic games. Retrieved from: http://www.climateaction.org/images/uploads/documents/sustainability_management_plan_aug 2013.pdf

Ross, Walker J \& Leopkey, Becca. (2017). The adoption and evolution of environmental practices in the Olympic Games. Managing Sport and Leisure, 22(1), 1-18.

Sinclar, Ian. (2012). Ghost milk: Recent adventures among the future ruins of London on the eve of the 2012 Olympics. Faber and Faber: London.

Todd, Jack. (2016, July 7). The 40-year hangover: How the 1976 Olympics nearly broke Montreal. Retrieved from https//www.theguardian.com/cities/2016/jul/06/40-year-hangover-19760olympic-gamesbroke-montreal-canada

Tokyo Organising Committee of the Olympic and Paralympic Games (TOCOG). (2016). High-level Sustainability Plan. Tokyo: Author. Retrieved from https://tokyo2020.org/en/games/sustainability/data/sus-plan-EN.pdf

Tokyo Organising Committee for the Olympic and Paralympic Games (TOCOG). (2019). Sustainability Progress Report: Tokyo 2020. Tokyo: Author. Retrieved from https://tokyo2020.org/en/games/sustainability/report/data/tokyo2020-games-susreport_EN.pdfor

United Nations Framework Convention on Climate Change. (1998). Kyoto protocol. Retrieved from http://kyotoprotocol.com/resource/kpeng.pdf

UN. (2000). UN Millennium Declaration. UN: Author. Retrieved from https://www.un.org/millennium/declaration/ares552e.pdf

van Hervejnin, Marjan (n.d.). Weighted summation (WSum). Retrieved from http://www.ivm.vu.nl/en/Images/MCA2_tcm234-161528.pdf

World Commission on Environment and Development. (1992). Agenda 21. UNCED: Author. Retrieved from https://sustainabledevelopment.un.org/outcomedocuments/agenda21

World Commission on Environment and Development. (1987). Our common future. Oxford: Oxford University Press.

World Commission on Environment and Development, (2015). Transforming our world. The 2030 agenda for sustainable development. UN General Assembly: Author. Retrieved from https://www.unfpa.org/resources/transforming-our-world-2030-agenda-sustainable-development 
Appendix 1. Evaluation Matrix for Rio 2016

\begin{tabular}{|c|c|c|c|c|c|c|c|c|c|}
\hline & \begin{tabular}{|l|} 
Water \\
Treatment \\
and \\
Conservation
\end{tabular} & \begin{tabular}{|l|} 
Environmental \\
Awareness
\end{tabular} & $\begin{array}{l}\text { Use and } \\
\text { management } \\
\text { of renewable } \\
\text { energy }\end{array}$ & $\begin{array}{l}\text { Games neutral in } \\
\text { carbon, air quality } \\
\text { and transport }\end{array}$ & $\begin{array}{l}\text { Protection } \\
\text { of soils and } \\
\text { ecosystems }\end{array}$ & \begin{tabular}{|l|} 
Sustainable \\
design and \\
onstruction
\end{tabular} & $\begin{array}{l}\text { Reforestation, } \\
\text { biodiversity } \\
\text { and culture }\end{array}$ & $\begin{array}{l}\text { Shopping and } \\
\text { ecological certification }\end{array}$ & $\begin{array}{l}\text { Solid Waste } \\
\text { management }\end{array}$ \\
\hline $\begin{array}{l}\begin{array}{l}\text { Rio } \\
2016 \\
\text { Score } \\
\text { of } 8\end{array} \\
\end{array}$ & \begin{tabular}{|l|}
1 \\
Clean up \\
pollution and \\
trash from \\
waterways \\
including \\
Guanabara \\
Bay and rivers \\
(1) \\
Add drainage, \\
sewage and \\
water \\
recycling \\
capabilities (1) \\
\\
\\
Polluted \\
Guanabara Bas) \\
bad high level of \\
viruses (1) \\
High \\
concentrations of \\
untreated sewagg \\
in the bay (1) \\
Low treatment of \\
sewage \\
outhing areas of \\
Guanabara (1)
\end{tabular} & \begin{tabular}{|l|}
5 \\
Sustainably \\
sourced fish for \\
athletes (1) \\
Meat produced \\
on farms that \\
didn't clear cut \\
(1) \\
Medals from \\
recycled \\
materials (1) \\
Sustainability \\
education \\
activities (1) \\
Sustainability \\
training \\
program for \\
workforce (1)
\end{tabular} & $\begin{array}{l}1 \\
\text { Cleaner fuels } \\
\text { for Olympic/ } \\
\text { Paralympic } \\
\text { fleet (1) } \\
\\
\\
\\
\end{array}$ & 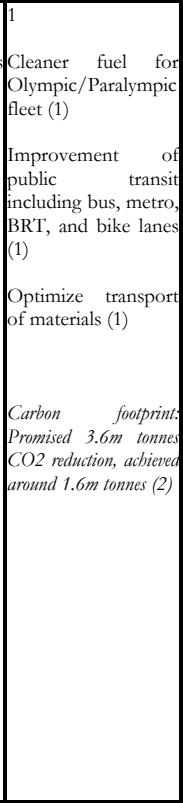 & $\begin{array}{l}-1 \\
\text { 'Clean } \\
\text { Games' and } \\
\text { reforestation } \\
\text { initiatives (1) } \\
\end{array}$ & \begin{tabular}{|l|} 
\\
Maracana \\
Stadium, Rio \\
de Janeiro \\
\\
Rational use of \\
resources, \\
efficiency and \\
minimization \\
of \\
environmental \\
impact in \\
venue design \\
and ruction \\
construction \\
(including \\
recycled \\
materials, \\
greenhouse gas \\
emissions, \\
water $\quad$ use, \\
environmental \\
impact, and \\
spills) (1) \\
Venues remain \\
nearly empty \\
or not utilized \\
post-games (1)
\end{tabular} & 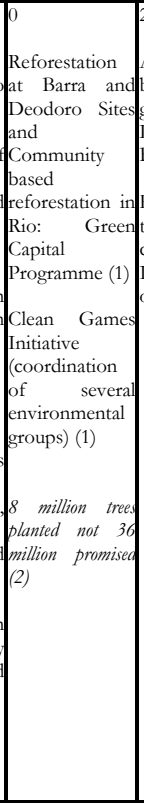 & $\begin{array}{l} \\
\text { All permanent venues } \\
\text { built by municipal } \\
\text { government will receive } \\
\text { LEED certification from } \\
\text { Brazil's PROCEL (1) } \\
\text { Forest management and } \\
\text { timber sourcing will be } \\
\text { certified by FSC, } \\
\text { INMETRO/CERFLOR, } \\
\text { or PEFC (1) }\end{array}$ & $\begin{array}{l}\text { Clean up of } \\
\text { dump sites (1) } \\
\text { Alignment and } \\
\text { implementation } \\
\text { of waste } \\
\text { management } \\
\text { plans for } \\
\text { construction } \\
\text { and responsible } \\
\text { management } \\
\text { and treatment } \\
\text { of solid waste } \\
\text { from the games } \\
\text { (1) } \\
\text { Failure to Clean } \\
\text { Guanabara Ba) } \\
\text { (1) }\end{array}$ \\
\hline
\end{tabular}

Appendix 2. Evaluation Matrix for Tokyo 2020

\begin{tabular}{|c|c|c|c|c|c|c|c|c|c|}
\hline & \begin{tabular}{|l|} 
Water \\
Treatment and \\
Conservation
\end{tabular} & \begin{tabular}{|l} 
Environmental \\
Awareness
\end{tabular} & $\begin{array}{l}\text { Use } \quad \text { and } \\
\text { management } \\
\text { of } r \text { renewable } \\
\text { energy }\end{array}$ & $\begin{array}{l}\text { Games neutral } \\
\text { in carbon, air } \\
\text { quality and } \\
\text { transport }\end{array}$ & $\begin{array}{c}\text { on of } \\
\text { and } \\
\text { ems }\end{array}$ & & $\begin{array}{l}\text { Reforestation, } \\
\text { biodiversity and } \\
\text { culture }\end{array}$ & \begin{tabular}{|l|} 
Shopping \\
and \\
ecological \\
certification
\end{tabular} & $\begin{array}{lr}\text { Wlid } & \text { Wast } \\
\text { lanagement }\end{array}$ \\
\hline $\begin{array}{l}\text { Tokyo } \\
2020 \\
\text { Score } \\
\text { of } \\
14\end{array}$ & $\begin{array}{l}\text { Improve water } \\
\text { circulation in } \\
\text { the city (1) } \\
\text { Recycled use of } \\
\text { rainwater in } \\
\text { venues (0) } \\
\text { Cleaning and } \\
\text { management of } \\
\text { Tokyo Bay and } \\
\text { rivers and } \\
\text { Restoration of of } \\
\text { water in parks } \\
\text { including Kokyo } \\
\text { Gaien National } \\
\text { Park (Imperial } \\
\text { Palace) (1) } \\
\text { Mixed - bacterid } \\
\text { levels of Tokyo Bay } \\
\text { very bigh at present } \\
\text { but plan in place to } \\
\text { screen bacteria (1) }\end{array}$ & 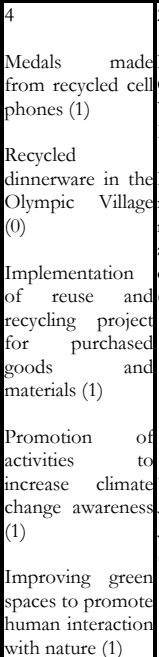 & \begin{tabular}{|l|} 
\\
Powering \\
Olympic \\
Village \\
Hydrogen $(0)$ \\
promoth \\
Promon \\
recycled \\
materials such \\
as timbers for \\
consumption \\
(1)
\end{tabular} & $\begin{array}{l}\text { Hydrogen fuel } \\
\text { cell cars (0) } \\
\text { Powering the } \\
\text { Olympic Village } \\
\text { with Hydrogen } \\
\text { (0) } \\
\text { Introduction of } \\
\text { systems for } \\
\text { sharing data on } \\
\text { the } \\
\text { environment, } \\
\text { including the } \\
\text { weather and air } \\
\text { quality (1) }\end{array}$ & $\begin{array}{l}\text { Sustainable } \\
\text { sourcing for } \\
\text { procurement } \\
\text { (0) } \\
\text { Management } \\
\text { of chemicals } \\
\text { in items } \\
\text { produced/ } \\
\text { given at the } \\
\text { games (0) } \\
\text { Use of low- } \\
\text { emission and } \\
\text { low-noise type } \\
\text { construction } \\
\text { machineries } \\
\text { (1) } \\
\text { Timbers not } \\
\text { sustainably } \\
\text { sourred (1) }\end{array}$ & \begin{tabular}{|l|} 
\\
New \\
Stadium, National \\
Harajuku (0) \\
Strategic planning \\
to use existing \\
venues (accounting \\
for $60 \%$ of venues) \\
(1) \\
High \\
Environmental \\
Performance \\
New in \\
(including recycling \\
materials, \\
installation \\
renewable energy \\
sources such as \\
geothermal, solar \\
power and passive \\
design, and lumber \\
relay, \\
rank 's' in CASBEE \\
assessment) (1)
\end{tabular} & 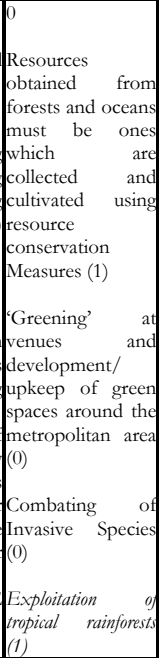 & \begin{tabular}{|l|}
2 \\
Sustainable \\
Sourcing \\
Code (1) \\
Tokyo GAP \\
certificate \\
system (1) \\
New venues \\
must rank 'S \\
in CASBEE \\
assessment \\
(1) \\
Timbers no \\
sustainably \\
sourced (1)
\end{tabular} & $\begin{array}{l}1 \\
\text { Goal of 'Zero } \\
\text { Wasting' (0) } \\
\text { Reduction of } \\
\text { the edible part } \\
\text { of food waste } \\
\text { by optimized } \\
\text { management } \\
\text { systems (0) } \\
\text { Reduction of } \\
\text { the production } \\
\text { of new items by } \\
\text { using rentals } \\
\text { and leases to } \\
\text { procure items } \\
\text { (1) } \\
\text { Recycle of food } \\
\text { waste }(0) \\
\text { Reuse or recycle } \\
\text { of construction } \\
\text { wastes }(0)\end{array}$ \\
\hline
\end{tabular}

